\title{
USING REMOTE SENSING TECHNOLOGY ON THE DELIMITATION OF THE CONSERVATION AREA FOR THE JIANAN IRRIGATION SYSTEM CULTURAL LANDSCAPE
}

\author{
C. H. Wang ${ }^{\mathrm{a}, *}$ \\ ${ }^{a}$ Graduate Institute of Folk Art and Cultural Heritage, National Taipei University, New Taipei City, Taiwan \\ (ufjk0256@ms6.hinet.net)
}

\section{Commission}

KEY WORDS: Cultural Landscape, Remote Sensing, GIS

\begin{abstract}
:
In recent years the cultural landscape has become an important issue for cultural heritages throughout the world. It represents the "combined works of nature and of man" designated in Article 1 of the World Heritage Convention. When a landscape has a cultural heritage value, important features should be marked and mapped through the delimitation of a conservation area, which may be essential for further conservation work. However, a cultural landscape's spatial area is usually wider than the ordinary architectural type of cultural heritage, since various elements and impact factors, forming the cultural landscape's character, lie within a wide geographic area. It is argued that the conservation of a cultural landscape may be influenced by the delimitation of the conservation area, the corresponding land management measures, the limits and encouragements.
\end{abstract}

The Jianan Irrigation System, an historical cultural landscape in southern Taiwan, was registered as a living cultural heritage site in 2009. However, the system's conservation should not be limited to just only the reservoir or canals, but expanded to irrigated areas where farmland may be the most relevant. Through the analysis process, only approximately 42,000 hectares was defined as a conservation area, but closely related to agricultural plantations and irrigated by the system. This is only half of the 1977 irrigated area due to urban sprawl and continuous industrial expansion.

\section{INTRODUCTION}

\subsection{Cultural Landscape as a Cultural Heritage}

Cultural landscapes represent the "combined works of nature and of man". An irrigation system can be seen as a cultural landscape, especially an organically evolved landscape. The irrigation system would be also one of the important components for a rural landscape and its development, as the operation of the system would benefit agricultural production. Thus, not only the irrigation system's facilities, but the fields and even the village, could be considered part of an integral landscape. These would represent the agricultural production process and scenery. More than 100 sites have been nominated as World Heritage cultural landscapes, of which more than 50\% were continually evolving organic landscapes.

In 2005, the amendment to Taiwan's Cultural Heritage Preservation Act had been added the category of Cultural Landscapes. This included spaces and relevant environments for myths, legends, circumstances, historical events, community life and various ceremonies. The Act's Operational Guideline goes further giving specific details for these categories. These include the location of myths and legends; historical routes or cultural facts; religious landscapes; historical gardens; event locations; agricultural, industrial and transportation landscapes; irrigation and military facilities; and interactions between humans and the natural environment. Although these functional categories, unlike conceptual categories defined as World Heritage (Fowler, 2003), may lead to some misunderstandings at some sites due to restrictions with the limited list of categories. The cultural landscape provides new opportunities for a rural site that still functions today, but over time has been transformed and accumulated cultural significance.

\subsection{Cultural Landscape and GIS}

The conservation area of a cultural landscape should be defined for further conservation work. Sometimes it is close to the types of land use. Also, a conservation area should be a complete area. Although each parcel of land may have different uses, the whole image of the cultural landscape should be the result of the land's collective use, which then becomes the cultural landscape's theme.

A Geographic Information System (GIS) is widely used in landscape-scale research (Ayad, 2005; Bender et al., 2005; Fish et al., 2003). With a GIS integrated into the platform, various information sources, such as satellites and/or remote sensing, land use information, and other planning may affect the features of a cultural landscape. Information on the land use for each parcel of land was reclassified and weighted. Land close to agricultural plantations has a higher weight, while those used for industrial or commercial purposes and possibly harmful to agriculture, is lower. The kernel density estimation (KDE) method was also used, by which a single or minor discordant land use may be obscured, while a general and major land use would be revealed.

\section{JIANAN IRRIGATION SYSTEM AS A CULTURAL LANDSCAPE}

\subsection{Brief History of the Jianan Irrigation System}

The southern part of Taiwan is a relatively flat area. However, before the Jianan Irrigation System was built there were only local irrigation systems in the rural areas. These were dependent on the occasional rain-water. In 1920, the Japanese Colonial 
Government decided to build an irrigation system to improve the agricultural productivity of these plains. Construction began in 1920, and finished in 1930. More than 150,000 hectares of dry farmland that, in the past could only depend on inconsistent rainfall, were transformed into productive paddy fields. The system, stretching over $160,000 \mathrm{~km}$. consists of a reservoir, waterways, water gates, tunnels, aqueducts, inverted siphons and other facilities, and also an irrigation system and management organization that is still functioning to this day (Figure 1, Figure 2).

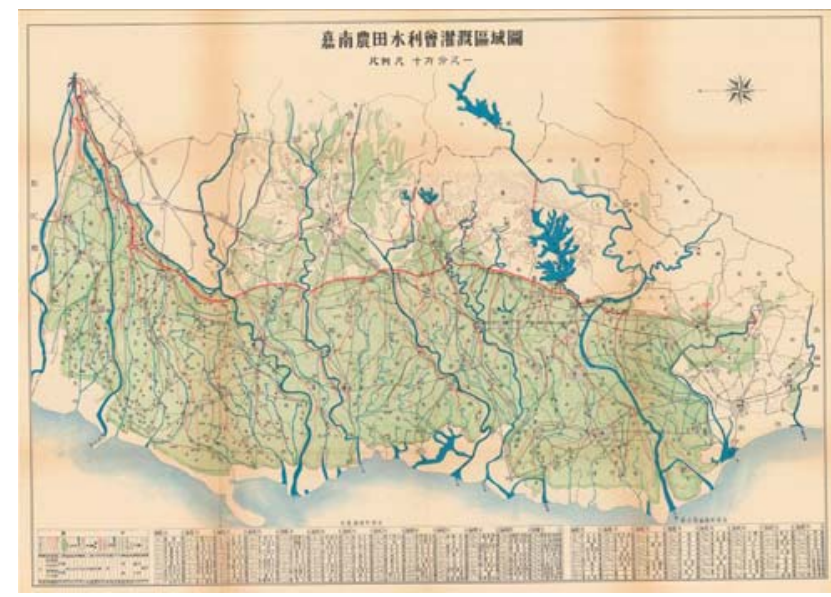

Figure 1. The Jianan Irrigation System's operations map

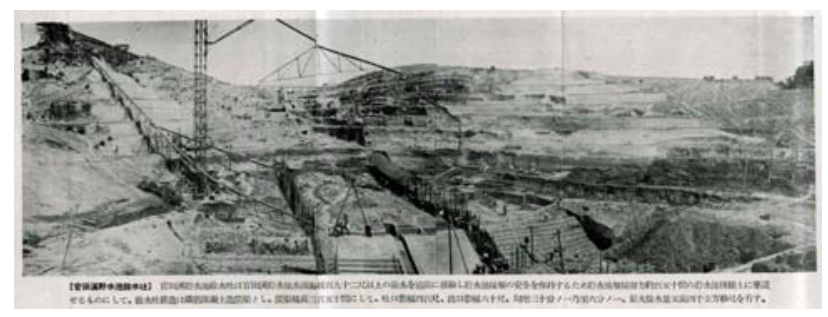

Figure 2. Construction of the Jianan Irrigation System's reservoir

Source: (Jianan Irrigation Association, 1930)

The Jianan Irrigation Association was also founded in 1920 to operate the system. This association, still functioning to this day, controls, operates, and manages the system, according to water demand. The maintenance of the system is also the Association's responsibility. These include the renovation of relevant facilities and repair of the waterways. However, the main structure and important elements of the system, such as the reservoir, main waterways and aqueducts, are still in their original state (Figure 3).

From an historical point of view, this system was an important mile-stone in Taiwan's agricultural development. From the technological point of view, the construction and operation of the system represents human ingenuity. From the landscape point of view, the system created a harmonious rural landscape, with elements of the system integrated into it. From the heritage point of view, it can be seen as an organically evolving cultural landscape. Important elements of the system represent human evolution under the influence of physical constraints and/or opportunities presented by the natural environment.
After the 2005 amendment to the Cultural Heritage Preservation Act, a Cultural Landscape category was added to the Act. In 2009 , the System was registered as one of Taiwan's legally cultural landscapes.

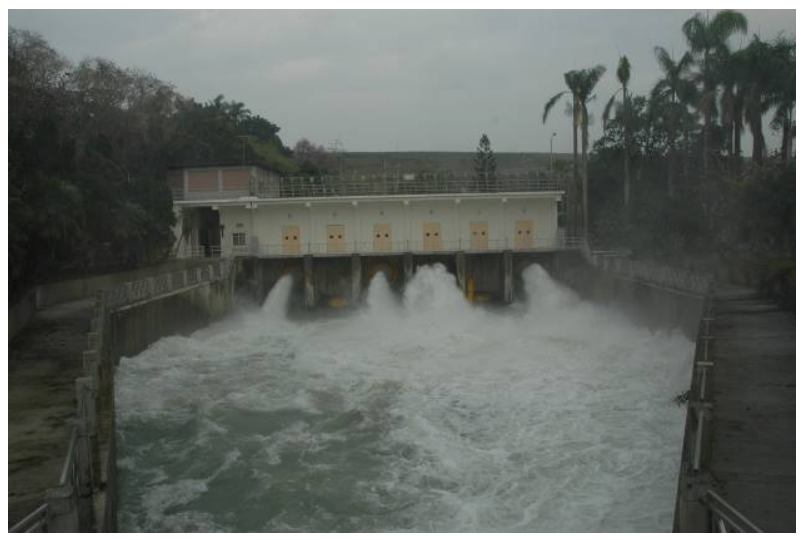

Figure 3. One of the facilities in the Jianan Irrigation System

\subsection{Core Value and Conservation of a Cultural Landscape}

From the cultural heritage point of view, a cultural landscape should be a site that reflects the interactions between people and the environment/land, not a "landscape" of cultural ideas, thinking, or viewpoints. It should be comprised of six basic components: a theme, people, functionality, the environment, objects, and time. A cultural landscape may be interpreted as a functioning process made by people, but at the same time some objects are part of the natural environment. Meanwhile, historicity has accumulated through a dynamic and changing process over time.

Although the cultural landscape concept is a new category in the cultural heritage field, it provides a new integral conservation idea where various elements in a site may have different contributions (Wang and $\mathrm{Fu}, 2014$ ). The conservation of a cultural landscape should not mean the protection of "objects" only. Conservation work no longer involves the preservation of buildings and facilities alone. The relevant environmental and industrial functions should be considered as a whole (Wang and Fu, 2011a). The core of managing a cultural landscape focuses on the relationship of interactions between people and their environment (Mitchell et al., 2009). The conservation of a cultural landscape should conserve characteristics of the landscape and its ever-changing features in its entirety, rather than the static condition of "objects". The functions that promote the operation of the landscape should be kept, so that objects and scenarios derived from those functions may be preserved or represented.

The Jianan Irrigation System and the Wushantou Reservoir is not only an irrigation system, but also an agricultural system that supports a functioning irrigation system that covers most of the irrigated area. Thus, the irrigation system's cultural landscape's conservation area may be delimited by the following principles:

(1) It is essential that each important physical object's space in the agricultural area should be included; 
(2) The irrigated area marked on the historical map, the contemporary zoning system in the regional plans and the real use of the land are considered comprehensively;

(3) The cultural landscape's conservation area is an integral idea. Therefore, specific monuments that embody the importance of the whole landscape should be protected by other legal means. (Figure 4)

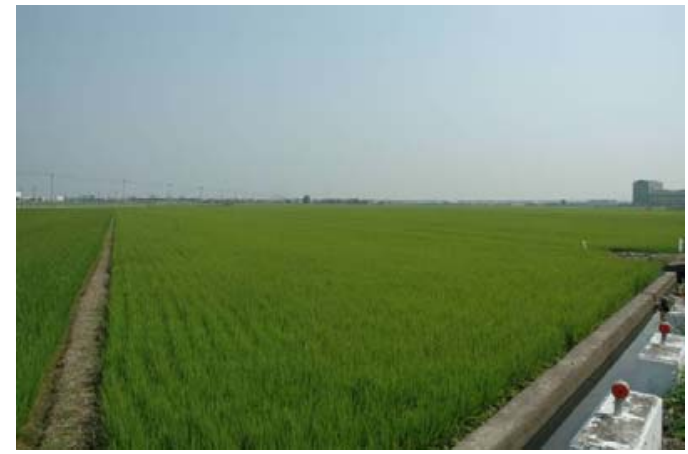

Figure 4. Planning should protect irrigated farms from unexpected changes

\subsection{Remote Sensing and the Conservation of Cultural Landscapes}

Since the conservation of a cultural landscape relies on continuous functioning, how the land is used both now and in the past, it is essential to delimitate a cultural landscape's conservation area. In this sense, large-scale cultural landscapes and landscape features require land use information that is usually acquired by remote sensing technology. Remote sensing might be helpful in evaluating the different land covers (Alhaddad et al., 2012). To study changes in the landscape and monitor the biological diversity at the biotope and landscape levels (Ihse, 1995), methods have been developed to describe and quantify changes to semi-natural vegetation and small biotopes and spatial patterns in ecological terms. The land use information, regarding other recent spatial elements, is integrated into the GIS system. At the same time a georeferenced historical map may provide additional original space information that has altered or changed over time. Any cultural heritage values are shown on these maps. The integral spatial information is helpful in the conservation and management decisions of an historical cultural landscape.

Besides the large-scale landscape, specific monuments within the whole landscape are much easier to record. Large span bridges or the irrigation system's aqueducts were recorded using 3D scanning technology.

\section{METHOD}

\subsection{Mapping of Maps and Orthophotos}

Historical maps were used for mapping the original irrigation system and irrigated farms. Maps prepared in 1977 were also used, as they may show the most complete distribution of the whole irrigation system, as the irrigated area has been reduced or scattered since then (Figure 5). The irrigation system's major and minor channels were also mapped into the GIS system. However, because the 1977 mapset is not a precise in-scale map it is necessary to adjust the spatial data to fit other in-scale maps, or recent orthophotos.

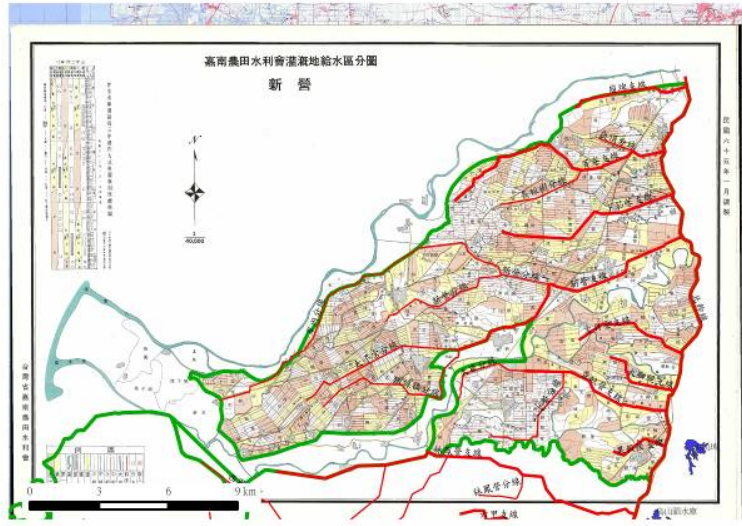

Figure 5. Mapping of the 1977 irrigation system

The other important map used in this project was Land Use Investigation of Taiwan published by the Minister of Interior's National Land Surveying and Mapping Center. The most recent land use information recorded on this map classified 9 major types of land use, and 103 sub-types (Figure 6) (National Land Surveying and Mapping Center, MOI, 2015). In this project, the irrigation's cultural landscape feature is represented by the common type of land use showing today's agricultural land, and can be compared with the proposed irrigated area marked on the historical map.

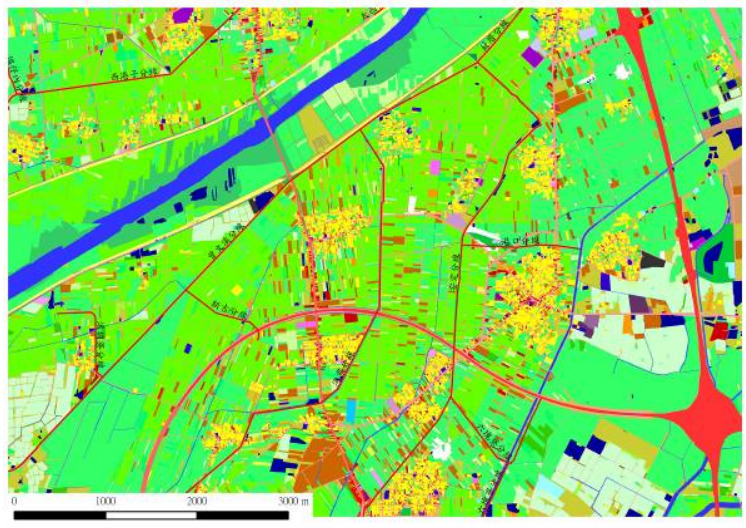

Figure 6. The Land Use Investigation of Taiwan

Finally, zoning maps for urban and regional planning were reviewed. These maps were used as a guide for spatial development. For instance, the agricultural land in a housing zone will undoubtedly be developed for housing in the near future. Irrelevant zoning should be excluded in the planning of the conservation area, even if it is used for a relevant purpose at present.

\subsection{Evaluation}

Due to urban sprawl and industrial development, more and more farm-lands are being appropriated for other functions, such as housing or factories. Once land has been used for different purposes such as new real estate, or even industrial factories, it will be an almost irreversible change to rural land (Wang and Fu, 2011b). If the land's common use has changed from agriculture to another that is quite irrelevant to an historical irrigation system cultural landscape, there is little reason to protect it through the delimitation of conservation areas and other preservation codes. To protect the link between "irrigation facilities-people-agriculture", the conservation area should focus on those regions in the entire irrigated area, where 
the land is in an agricultural zone and still being used for agriculture.

From the Land Use Investigation of Taiwan, different types of land use were weighted according to their agricultural link. Some types of land use such as livestock, schools and housing, although necessary in a rural landscape, are different from the preferred cultural landscape image of flat plains covered with crops irrigated by the system. So each patch of land may have a lower weighted score $\left(100 \mathrm{~m}^{*} 100 \mathrm{~m}\right)$. Some other types of land use such as manufacturing industries, retail and wholesale selling, may be irrelevant to the irrigation's cultural landscape, and potentially even destructive to the landscape's image. The earth stone adopts the field that will be given the lowest weighted score. Some weighted score descriptions are listed in Table 1.

\begin{tabular}{|c|c|c|}
\hline Category & Description & $\begin{array}{l}\text { Weighted } \\
\text { Score } \\
(+5 \text { to }-5)\end{array}$ \\
\hline $\begin{array}{l}\text { Rice paddies } \\
\text { Arid area } \\
\text { Fruit trees }\end{array}$ & $\begin{array}{l}\text { The most relevant type of } \\
\text { land use in the irrigation } \\
\text { system's cultural } \\
\text { landscape }\end{array}$ & +5 \\
\hline Left uncultivated & $\begin{array}{l}\text { This type refers to those } \\
\text { lands that are temporarily } \\
\text { uncultivated, but may be } \\
\text { cultivated again in the } \\
\text { future }\end{array}$ & +1 \\
\hline $\begin{array}{l}\text { Aquaculture } \\
\text { Livestock } \\
\text { Pasture }\end{array}$ & $\begin{array}{l}\text { Although these may refer } \\
\text { to an agricultural use, } \\
\text { these are different to the } \\
\text { preferred irrigation } \\
\text { cultural landscape image }\end{array}$ & -1 \\
\hline $\begin{array}{lr}\text { High-speed railroad } \\
\text { Provincial road, } \\
\text { expressway }\end{array}$ & $\begin{array}{l}\text { These continuous large } \\
\text { structures disrupt the } \\
\text { area's preferred sightlines }\end{array}$ & $\begin{array}{l}-5 \\
-3\end{array}$ \\
\hline $\begin{array}{l}\text { Universities, } \\
\text { colleges } \\
\text { institutes }\end{array}$ & $\begin{array}{l}\text { Most buildings in } \\
\text { universities or similar } \\
\text { institutes are large in } \\
\text { volume which may } \\
\text { disturb preferred extended } \\
\text { sight in the plain }\end{array}$ & -3 \\
\hline Others & & +0 \\
\hline
\end{tabular}

Table 1. Land use categories and their weight scores

The Kernel Density Estimation method shows the QGIS and SAGA. The common land use preferred for the irrigation system's cultural landscape image are marked by different weighted scores for each patch of land. In the KDE, the search radius is set as $300 \mathrm{~m}$, while the cell size is set as $100 \mathrm{~m}$.

\subsection{Adjustment}

After the evaluation process, the most relevant area of the irrigation system's cultural landscape is marked. However the final conservation area of the cultural landscape requires a minor adjustment.

Firstly, those patches of land not located in the urban or regional planning's agricultural zone are excluded. Secondly, a conservation area should be as complete as possible, which means the fragmented or oddly shaped parts of a conservation area need to be adjusted. The shape factor examination is used, while relevant types of land use in the adjusted area should be considered independently.

$$
\left(4 * \mathrm{Pi}^{*} \text { Area }\right) /\left(\text { Perimeter }^{\wedge} 2\right)
$$

Thirdly, the boundary of a conservation area should be easily recognized. Boundaries should be readily identifiable and should follow natural physical features as these are unlikely to change and are more easily understood on the ground, than the straight-line boundaries drawn on maps (Lucas, 1992). In the case of the Jianan irrigation system's cultural landscape, the boundaries are aligned with man-made infrastructures.

Finally, a field trip investigation was conducted to recheck the conservation area's boundary. Since the landscape is a perceivable part of the earth's surface (Antrop, 2003), the most significant image of a cultural landscape still needs to be viewed by man from the ground. Also, some minor changes may be necessary due to the time lag in the Land Use Investigation of Taiwan.

\section{RESULT AND DISCUSSION}

\subsection{Result}

4.1.1 Area: in Tainan City, the whole area of the cultural landscape, according to historical maps, is approximately 79,935 hectares, while the recommended conservation area, after adjustment, is only 42,109 hectares (Figure 7).

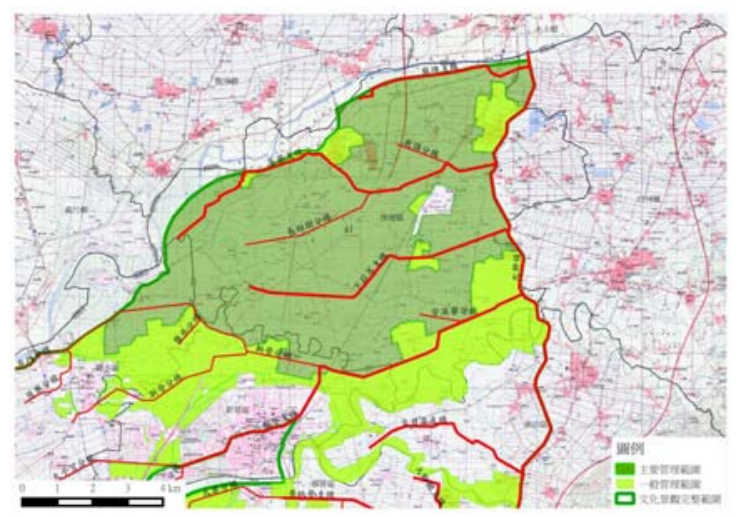

Figure 7. Part of the Jiannan Irrigation System's Cultural Landscape's Conservation Area

4.1.2 Exclusion: the area that has been populated or extensively developed is excluded. However, some minor illegal use in the agricultural zone was easily marked. This will become the basic data for rectifying further illegal land use.

4.1.3 Landscape Feature: Most images in the conservation area delimitated from the analysis and evaluation of the Land Use Investigation of Taiwan, are quite consistent with the preferred landscape image of the irrigation system's cultural landscape. Some of the new housing or factories that have been built on farms are not shown in the Land Use Investigation due to time lags.

\subsection{Discussion}

From historical maps and a recent land use map, it is obvious that the agricultural land has been changing and disappearing. Some land along the irrigation canal has changed from farming to other uses. Therefore, in the future it may be difficult to 
preserve these canals and their original function. Although a landscape cannot be fossilized into a specific image, changes in an evolving landscape are unavoidable, so it is necessary to manage any landscape changes where the cultural heritage value is preserved. Landscapes are multifunctional. Land use plans cannot be restricted by a pre-determined use for each field or parcel of land (Antrop, 2000).

While the information contained in the Land Use Investigation of Taiwan is applicable, the definition of categories may still have some limits for delimitation. Greenhouses are acceptable in an irrigation system's cultural landscape due to the agricultural process that may continue to function in an innovative sense (Figure 8). However, some greenhouses structures have changed the land cover to irreversible concrete. In this sense, the greenhouse is harmful to an irrigation system's cultural landscape since it is seen as an unsustainable structure (Figure 9). This information could not be identified through the Investigation, and a field trip investigation was necessary.

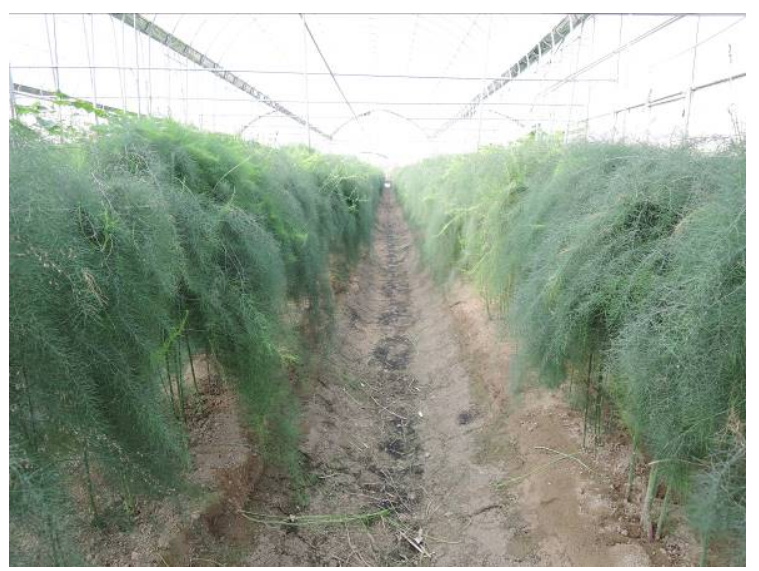

Figure 8. An asparagus greenhouse

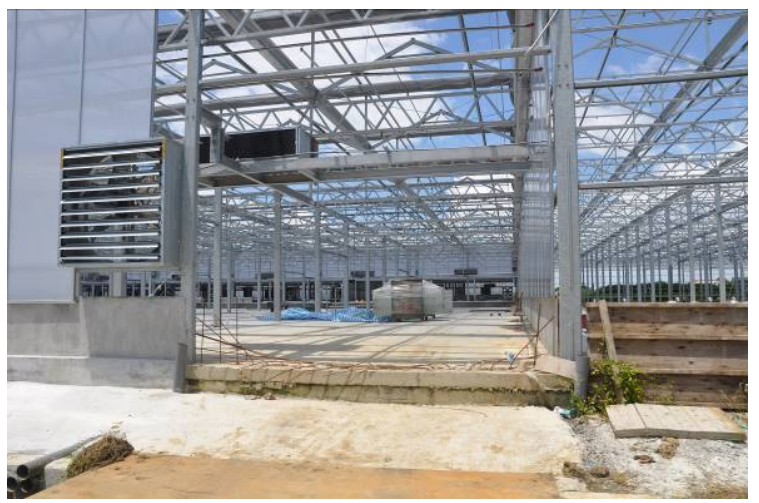

Figure 9. An orchid greenhouse with a concrete floor

A mobile image catcher may provide more low-cost and realtime information, compared to interpretive data published by a government authority. However, large numbers of images are not a systematic, precise, or fast method for identifying the images' features and "feeling", since these evaluations are based on human emotions.

On the other hand, a UAV (Unmanned Aerial Vehicle) can become the new tool for a personal, low-cost and real-time image catching solution on the landscape scale. However, it still faces numerous safety, security and privacy restrictions. The guidelines for the reasonable use of a UAV should be formulated.

\section{CONCLUSION}

In this project, land use categories with weighted scores, GIS, and KDE were applied on the basis of the Land Use Investigation of Taiwan, and a preliminary conservation area for the Jianan Irrigation System's Cultural Landscape was outlined. This process may provide a useful scale for a preliminary landscape that is based on the close relationship between the landscape image and land use. From the field trip investigation, the preferred landscape feature was also recognized, based on correct land use information.

In the future, with different geographic information and open data, and the development of computer scripts, it is possible to create a more efficient analysis model for other cultural landscapes. It is also useful to indicate changes that occur in the landscape over time, and advise previous conservation areas by comparing different land use information.

\section{ACKNOWLEDGEMENTS}

This paper is based on the research project of "Conservation and Management Plan of the Wushantou Reservoir and the Jianan Irrigation System's Cultural Landscape" directed by Ping-Sheng Wu, Fang-Chieh Jung, and Yu-Hua Tsai, National Cheng Kung University, Tainan, Taiwan. The author is the research team's project researcher.

\section{REFERENCES}

Alhaddad, B., Arellano, B.E., Roca, J., 2012. Urban Detection and Morphology: Comparative Analysis of Selective "Megacities." ISPRS - International Archives of the Photogrammetry, Remote Sensing and Spatial Information Sciences XXXIX-B7, 381-386.

Antrop, M., 2000. Background concepts for integrated landscape analysis. Agriculture, Ecosystems \& Environment 77(1-2), 17-28.

Antrop, M., 2003. The Role of Cultural Values in Modern Landscapes - The Flemish Example, in: Palang, H., Fry, G. (Eds.), Landscape Interfaces: Cultural Heritage in Changing Landscapes, Landscape Series. Kluwer Academic Publishers, Dordrecht; Boston, pp. 91-108.

Ayad, Y.M., 2005. Remote sensing and GIS in modeling visual landscape change: a case study of the northwestern arid coast of Egypt. Landscape and Urban Planning 73(4), 307-325.

Bender, O., Boehmer, H.J., Jens, D., Schumacher, K.P., 2005. Using GIS to analyse long-term cultural landscape change in Southern Germany. Landscape and Urban Planning 70(1-2), $111-125$.

Fish, R., Haines-Young, R., Rubiano, J., 2003. Stakeholder Landscape and GIS: Institutional Visions of Landscape and Sustainability in the Management of the Sherwood Natural Area, UK, in: Palang, H., Fry, G. (Eds.), Landscape Interfaces: Cultural Heritage in Changing Landscapes, Landscape Series. Kluwer Academic Publishers, Dordrecht; Boston, pp. 147-161. 
Fowler, P., 2003. World Heritage Cultural Landscapes 19922002, World Heritage Papers. UNESCO World Heritage Centre, Paris.

Ihse, M., 1995. Swedish agricultural landscapes - patterns and changes during the last 50 years, studied by aerial photos. Landscape and Urban Planning 31(1-3), 21-37.

Jianan Irrigation Association (Ed.), 1930. Jianan Irrigation Construction Note. Jianan Irrigation Association.

Lucas, P.H.C., 1992. Protected Landscapes: a Guide for Policy-makers and Planers. Chapman \& Hall, London.

Mitchell, N., Rössler, M., Tricaud, P.-M. (Eds.), 2009. World Heritage Cultural Landscapes - A Handbook for Conservation and Management. UNESCO World Heritage Centre, Paris.

National Land Surveying and Mapping Center, MOI, 2015. Land Use Investigation of Taiwan. "Land Use Classification". http://lui.nlsc.gov.tw/LUWeb/eng/Content_e.aspx (26 June 2015).

Wang, C.-H., Fu, C.-C., 2011a. The Conservation of Disappearing Sugar Industry Cultural Landscapes in Taiwan. Journal of Asian Architecture and Building Engineering 10(1), $1-6$.

Wang, C.-H., Fu, C.-C., 2011b. The Sustainable Development of the Cultural Landscape of Jianan Irrigation System in Taiwan. Presented at the ICOMOS 17th General Assembly and Scientific Symposium, Paris, France.

Wang, C.-H., Fu, C.-C., 2014. Dynamic and Diverse Conservation Approaches for an Historical Irrigation System: A Cultural Landscape in Taiwan. Journal of Asian Architecture and Building Engineering 13(1), 25-32. 